\title{
VSS Degradation Kinetics in High Temperature Aerobic Digestion and Microbial Community Characteristics
}

\author{
Yunfen Shi $1 D$ and Huimin Ren \\ School of Chemical Engineering, Northeast Electric Power University, Jilin 132012, China \\ Correspondence should be addressed to Yunfen Shi; 928830935@qq.com
}

Received 3 December 2017; Accepted 13 March 2018; Published 23 April 2018

Academic Editor: Giuseppe Nano

Copyright ( 2018 Yunfen Shi and Huimin Ren. This is an open access article distributed under the Creative Commons Attribution License, which permits unrestricted use, distribution, and reproduction in any medium, provided the original work is properly cited.

\begin{abstract}
Piggery wastewater is a kind of high concentration organic wastewater with high concentration of pollutants, large amount of emissions, and serious environmental pollution and is difficult to deal with. Piggery wastewater was treated with autothermal hyperthermia aerobic digestion process (ATAD) and its biodegradation kinetics was studied. The ATAD system was automatically heated up and the reaction temperature rose from ambient temperature of $20^{\circ} \mathrm{C}$ to a maximum temperature of $64^{\circ} \mathrm{C}$. Based on Arrhenius formula, the empirical model is obtained through dimensional analysis. The removal of volatile suspended solids (VSS) was correlated with the initial VSS concentration, water inlet temperature, aeration rate, and agitation rate in the model. In the empirical model, the apparent activation energy was $2.827 \mathrm{~kJ} \cdot \mathrm{mol}^{-1}$. The exponentials for the initial VSS concentration, aeration rate, and stirring rate were $1.0587,-0.0976$, and -0.1618 , respectively. The correlation coefficient of the exponential factor was 0.9971 . The VSS removal efficiency predicted by the model was validated with an actual test, showing a maximum relative deviation of $8.82 \%$. Sludge systems show a lower diversity of microbial populations and Bacillus occupies a very important position in the reactor. The data obtained will be useful for optimizing piggery wastewater treatment process. The new model provided good theoretical guidance with good practicality.
\end{abstract}

\section{Introduction}

With the continuous expansion of pig industry, piggery wastewater production continued to increase [1]. Piggery wastewater contains a lot of nitrogen and organic matters, which has posed serious threats to the environment and human health [2]. There are three main approaches to removing manure from piggery in China, namely, urinefree manure (UFM), combined manure with urine (CMU), and soaked manure with urine (SMU). As a traditional mode, UFM collection has been widely used in China $[3,4]$. Numerous studies have been conducted on the treatment of piggery wastewater. For example, Zhang et al. [5] studied anaerobic codigestion of piggery wastewater and food waste and identified the key factors governing codigestion performance. Han et al. [2] investigated the effect of feeding strategy on the treatment of swine wastewater, showing that the feeding ratio had a more significant effect on the removal of phosphorus and nitrogen than on the removal of chemical oxygen demand (COD) in the sequencing batch reactor (SBR) system.

Pig manure wastewater generally contains high concentrations of COD, $\mathrm{N}$ (nitrogen), $\mathrm{P}$ (phosphorous), pathogenic bacteria, organic matters, and nutrients [6]. At present, incineration technology is predominant in the treatment of high concentrations of pathogenic microorganisms. However, it exposes many disadvantages, such as high energy consumption and complicated operation [7]. Self-heating high temperature aerobic digestion process uses the thermophilic microbial metabolism (i.e., cell death, hydrolysis, and biosynthesis) so as to achieve the degradation of organic matters and the eradication of pathogens. In this process, the microorganisms use oxygen for their own oxidative decomposition, releasing heat. There are two main roles in the ATAD process: the degradation of organic matters by microorganisms under the presence of active enzymes and the disintegration of extracellular enzymes. The second 
TABLE 1: Compositions of the piggery wastewater.

\begin{tabular}{|c|c|c|c|c|c|}
\hline Influent VSS $(\mathrm{g} / \mathrm{L})$ & $\mathrm{TP}(\mathrm{mg} / \mathrm{L})$ & $\mathrm{NH}_{3}-\mathrm{N}(\mathrm{mg} / \mathrm{L})$ & $\mathrm{TN}(\mathrm{mg} / \mathrm{L})$ & $\mathrm{COD}_{\mathrm{Cr}}(\mathrm{mg} / \mathrm{L})$ & $\mathrm{pH}$ \\
\hline $7-55$ & $40-50$ & $1100-1300$ & $1200-1400$ & $5000-6000$ & $8.0-9.0$ \\
\hline
\end{tabular}

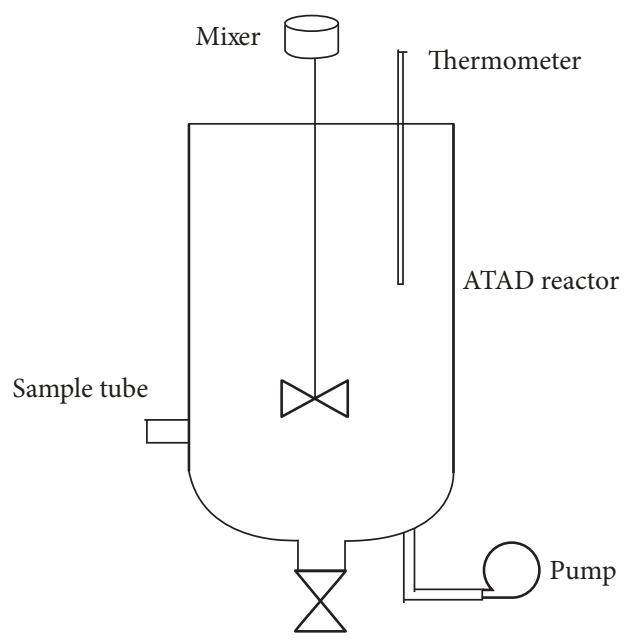

FIGURE 1: The sketch map of the ATAD experimental equipment.

process has a key effect on the inactivation of pathogens and the removal of VSS [8]. ATAD is more stable than other sludge treatments (e.g., anaerobic digestion) and is not susceptible to fluctuations in operating conditions. Therefore, ATAD has gained widespread attention in the field of environmental engineering, and some ATAD processes have been successfully applied in other fields. [9-11].

During aerobic digestion of sludge, the microorganisms are in the endogenous respiration phase, so the reaction rate and biomass follow the first-order reaction equation [12]. The most commonly used model is Adams proposed model. However, the Radall study found that solid suspended solids decreased during the remaining activated sludge digestion, suggesting that the Adams model is not the same as the actual situation [13]. Gomez et al. [14, 15] did not consider the effect of temperature. They put the ATAD model as ASM1 model.

In order to provide theoretical guidance for wastewater treatment and engineering design, the effects of parameters such as agitation rate, reaction temperature, aeration rate, and influent concentration on VSS removal were studied. The empirical model of laboratory scale was established.

\section{Materials and Methods}

2.1. Wastewater Sources and Water Quality. The raw manurefree piggery wastewater was collected from a local pig farm in Harbin, China. Influent quality of the wastewater fluctuates along with breeding seasonality. Compositions of the piggery wastewater and the experimental operation parameters are summarized in Table 1.

2.2. ATAD Reaction System. As shown in Figure 1, the device of ATAD consists of a mixing system, an aeration system, and a thermometer. A water bath was used to maintain the reaction temperature. The main body of the reactor is wrapped with a $2 \mathrm{~cm}$ thick insulating material. The effective volume of the reactor is $2.8 \mathrm{~L}$.

In the experiment, a prescribed amount of piggery wastewater was added to the reactor. The stirring speed and aeration rate were adjusted. The temperature of the reaction was measured using a thermometer and adjusted through the water bath. There is a sampling tube in the bottom of the reactor. In order to minimize the heat loss caused by the temperature difference between the environment and the reaction system, the temperature of the water bath is about $5^{\circ} \mathrm{C}$ lower than the temperature of the reactor (except Section 3.4). In addition, in order to keep the amount of water in the reactor constant, deionized water of the same amount of the same temperature was added to the reactor daily. The reaction temperature was $20-60^{\circ} \mathrm{C}$, the stirring rate was $125-215 \mathrm{r} \cdot \mathrm{min}^{-1}$, and the aeration rate was $10-30 \mathrm{~L} \cdot \mathrm{h}^{-1}$.

2.3. Analytical Methods. The effects of influent concentration, aeration amount, and stirring speed on the reaction temperature, the removal rate of TSS and VSS, and the reaction time were investigated. TSS, VSS, $\mathrm{NH}_{3}-\mathrm{N}$, phosphorus $(\mathrm{P})$, alkalinity, $\mathrm{pH}, \mathrm{COD}_{\mathrm{Cr}}$, dissolved oxygen (DO), and temperature were measured once a day, and $\mathrm{BOD}_{5}$ was measured once every four days. These indicators were used to reflect the operation of the ATAD reactor. At the same time, we also evaluated the number of total flora, roundworm eggs, fecal coliforms, fecal streptococci, and salmonella to assess the contribution of the ATAD process to sludge stabilization. The analytical standard methods were adopted.

Microbial population structure analysis was performed using 454 high-throughput sequencing method; the steps include (1) genomic DNA extraction; (2) PCR amplification; (3) fluorescence quantification; (4) MiSeq sequencing; (5) the OTU division of the sequence.

2.4. Domestication Process. Two litters of activated aerobic sludge, taken from Jilin Sewage Treatment Plant, was placed in a $2.5 \mathrm{~L}$ glass reaction vessel combined with aeration and stirring apparatus. The jar was firstly placed in the water bath thermostat and the insulation layer was added around it to prevent heat loss. The temperature of the water bath was compatible with the system temperature (below system $1 \sim 2^{\circ} \mathrm{C}$ ). The aeration rate was adjusted to $10 \sim 15 \mathrm{~L} \cdot \mathrm{h}^{-1}$ and stirring speed to $180 \sim 200 \mathrm{r} \cdot \mathrm{min}^{-1}[16]$.

The activated sludge was cultured for 7 days and the temperature and settling ratio (SV) were measured daily. After 7 days of domestication, aerobic sludge volume has been reduced by about $1 / 3$. The temperature can be automatically increased, and the maximum temperature reached $62^{\circ} \mathrm{C}$, indicating that the success of domesticated strained. 


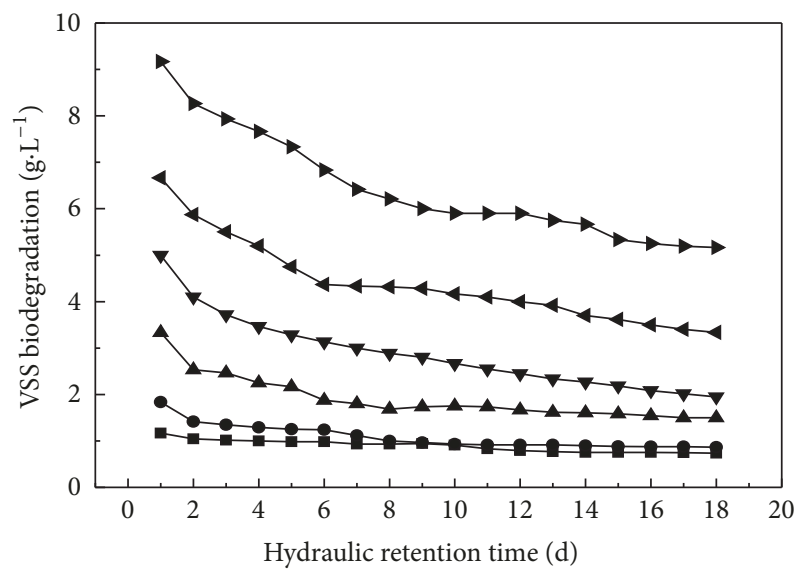

FIGURE 2: Effect of concentration on VSS removal. Concentration/g. $\mathrm{L}^{-1}:$ - 7; 11; $\boldsymbol{\Delta} 20 ; \boldsymbol{\nabla} 30 ; \triangleleft 40 ; \bullet 50$.

By changing the temperature and sludge volume, the thermophilic bacteria that were domesticated successfully can be used as bacteria into the reactor.

\section{Result Analysis}

3.1. The Effect of Feed Concentration on VSS Removal Efficiency. Figure 2 shows the degradation results at different feed VSS concentrations in ATAD at an initial temperature of $25^{\circ} \mathrm{C}$. The feed VSS concentration varied from 7.00 to $55.00 \mathrm{~g} \cdot \mathrm{L}^{-1}$, and the effluent VSS concentrations ranged from 4.40 to $31.00 \mathrm{~g} \cdot \mathrm{L}^{-1}$ on the 17 th day of reaction. Removal efficiency of VSS ranged from $37.14 \%$ to $61.00 \%$. When the feed VSS concentration was as high as $40 \mathrm{~g} \cdot \mathrm{L}^{-1}$, the VSS removal efficiency was $52.08 \%$, indicating that the ATAD process was applicable to biodegradation of a wide range of VSS concentrations. However, when the VSS concentration is greater than $30 \mathrm{~g} \cdot \mathrm{L}^{-1}$, the viscosity of material increases so that the mixing is poor and oxygen transfer is inhibited. At low VSS concentrations (below $30 \mathrm{~g} \cdot \mathrm{L}^{-1}$ ), the self-heating is not enough to maintain a relatively high temperature and degradation rate $[17,18]$. The removal efficiency of Ascaris eggs in the ATAD system was $100 \%$. When the feed concentration was high (greater than $30 \mathrm{~g} \cdot \mathrm{L}^{-1}$ ), the removal rates of the total numbers of flora and the number of fecal coliforms and Streptococcus faecalis were higher. The removal rate of fecal coliforms reached $99.95 \%$ and the fecal coliform removal rate reached $99.99 \%$ when the sludge concentration was $40 \mathrm{~g} \cdot \mathrm{L}^{-1}$. When the sludge concentration was $30 \mathrm{~g} \cdot \mathrm{L}^{-1}$, the removal rate of $S$. faecalis was $99.94 \%$. When the feed concentration was high, the organic content was large. Oxidative decomposition of the heat can effectively increase the temperature of the system, which is conducive to the inactivation of pathogens. Thus, the optimum influent VSS concentration is $30.00 \mathrm{~g} \cdot \mathrm{L}^{-1}$.

3.2. The Effect of Stirring Rates on VSS Biodegradation. Better mixing is needed for mass transfer, reaction substrate, DO,

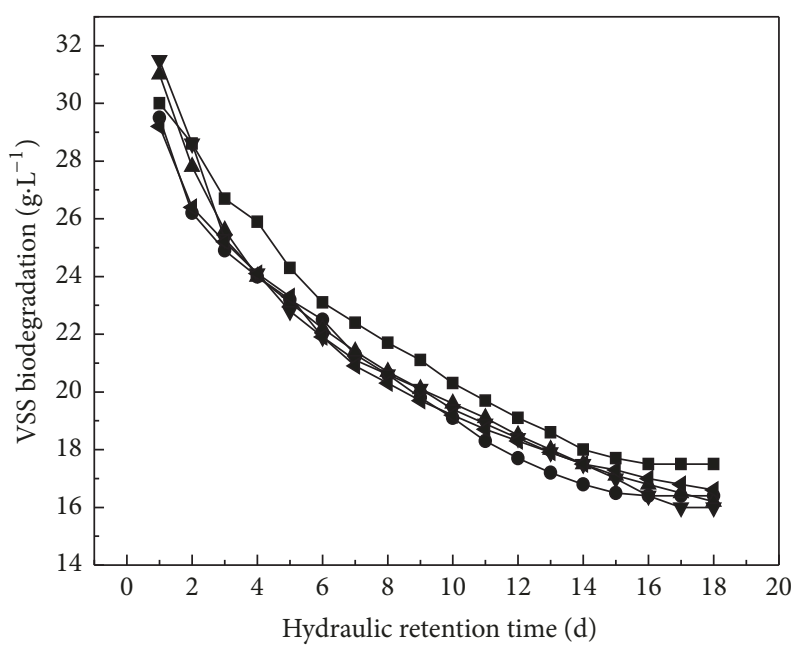

FIGURE 3: The influence of stirring rate on VSS removal. Stirring rate $/ \mathrm{r} \cdot \mathrm{min}^{-1}: \mathbf{1} 125 ; \bullet 145 ; \boldsymbol{\Delta} 165 ; \boldsymbol{\nabla} 185 ; \triangleleft 215$.

and thermophilic bacteria. Mixing rate is an important factoring affecting mass transfer, reaction substrate, concentrations of DO, and thermophilic bacteria [1]. The feed VSS concentration was $29.20-31.50 \mathrm{~g} \cdot \mathrm{L}^{-1}$, and the reaction temperature finally reached $62^{\circ} \mathrm{C}$ from room temperature. The effects of stirring rate on the VSS degradation are shown in Figure 3. At the same feed VSS concentration and aeration rate, low mixing intensity (below $185 \mathrm{rpm}$ ) was not enough for fully mixing, adequate endogenous respiration, complete heat release, quick increase of self-heating rate in the system, and high VSS removal rate. However, when the stirring rate was increased to $215 \mathrm{rpm}$, the self-heating rate in the system declines and was $4.0^{\circ} \mathrm{C} \cdot \mathrm{d}^{-1}$ in the first 12 days, with a maximum VSS removal efficiency of $43.15 \%$. When the stirring rate was $185 \mathrm{rpm}$, the biodegradation rate of VSS increased by $6.05 \%$ compared to that at $215 \mathrm{rpm}$. Ascaris egg removal rates had reached $100 \%$. When the stirring rate was $185 \mathrm{rpm}$, the removal rate of the total bacterial population was the highest, reaching $99.95 \%$. Higher mixing intensity may dissipate more reaction heat and decrease the temperature in the system. Thus, $185 \mathrm{rpm}$ was considered as the optimal stirring rate.

3.3. The Effect of Aeration Rate on VSS Biodegradation. At the VSS concentration of $30 \mathrm{~g} \cdot \mathrm{L}^{-1}$, five different aeration rates $\left(10,15,20,25\right.$, and $\left.30 \mathrm{~L} \cdot \mathrm{h}^{-1}\right)$ were used at stirring rate of $185 \mathrm{rpm}$ with running for 18 days. When the aeration rate was $10 \mathrm{~L} \cdot \mathrm{h}^{-1}$, the average temperature rising rate in the reactor is $2.07^{\circ} \mathrm{C} \cdot \mathrm{day}^{-1}$, the system temperature reaches $61^{\circ} \mathrm{C}$ with the removal rate of VSS reaching $52 \%$. When the aeration rate was $20 \mathrm{~L} \cdot \mathrm{h}^{-1}$, the VSS removal rate was the most efficient, reaching $50.32 \%$, while the sludge stabilization standard was achieved, and the final temperature of the system reached $63^{\circ} \mathrm{C}$. When the aeration rate was $30 \mathrm{~L} \cdot \mathrm{h}^{-1}$, the removal rate of VSS was $45.27 \%$, which was $12.8 \%$ lower than that of $15 \mathrm{~L} \cdot \mathrm{h}^{-1}$. When the oxygen supply was less than $15 \mathrm{~L} \cdot \mathrm{h}^{-1}$, the oxygen needed for aerobic digestion of microorganisms cannot be 
TABLE 2: The rate constants in the empirical model.

\begin{tabular}{lcc}
\hline Temperature $\left({ }^{\circ} \mathrm{C}\right)$ & $K(\mathrm{mg} / \mathrm{L} \cdot \mathrm{d})$ & Correlation coefficient \\
\hline 20 & 1.1391 & 0.9963 \\
30 & 1.1845 & 0.9847 \\
40 & 1.22 & 0.9831 \\
50 & 1.2718 & 0.9927 \\
60 & 1.3073 & 0.9914 \\
\hline
\end{tabular}

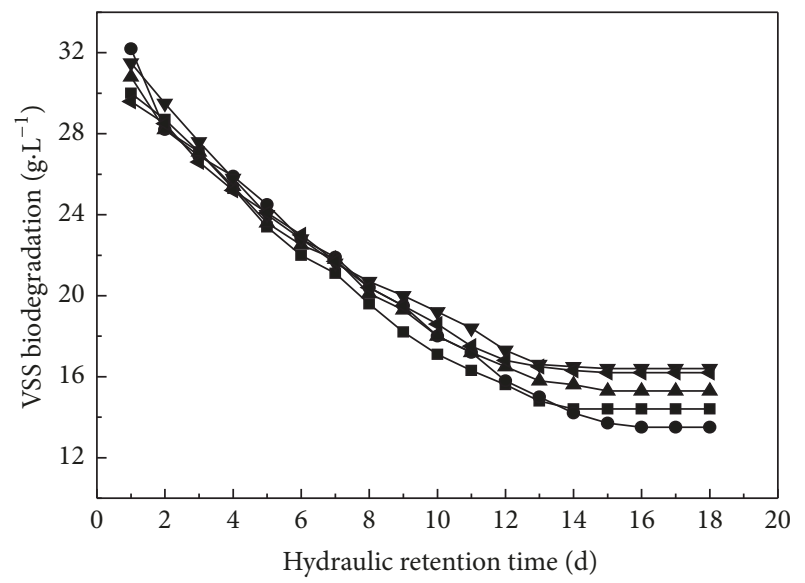

FIGURE 4: The influence of aeration rate on VSS removal. aeration rate/L.h $\mathrm{h}^{-1}: 10 ; \bullet 15 ; \boldsymbol{\Delta} 20 ; \boldsymbol{\nabla} 25 ; \triangleleft 30$.

satisfied, resulting in poor microbial activity and slow VSS degradation. When the aeration rate is more than $20 \mathrm{~L} \cdot \mathrm{h}^{-1}$, the aeration will make the system heat dissipation, which will lead to the system temperature decrease, thereby affecting the removal of VSS. Under different aeration rates, the removal rates of Ascaris eggs were all $100 \%$. When the aeration rate was $15 \mathrm{~L} \cdot \mathrm{h}^{-1}$, the removal rate of total number of bacteria was the highest, reaching $99.99 \%$. As shown in Figure 4, the removal rates of VSS were the highest at the aeration rate of $15 \mathrm{~L} \cdot \mathrm{h}^{-1}$, which is considered as the best rate under the experimental conditions.

3.4. The Effect of Temperature on VSS Biodegradation. In general, the effect of temperature on reaction rate may be described by Arrhenius-type formula. The action rate increases with temperature considerably due to the exponential function of temperature [19]. Therefore, high temperatures were generally chosen. The influent VSS was about $30 \mathrm{~g} \cdot \mathrm{L}^{-1}$, the aeration rate was $15 \mathrm{~L} \cdot \mathrm{h}^{-1}$, and the stirring rate was $185 \mathrm{rpm}$. The temperature changed in the range of $20-60^{\circ} \mathrm{C}$. Figure 5 shows that the VSS biodegradation rate increased with temperature significantly. At $60^{\circ} \mathrm{C}$, the VSS removal rate was $61.19 \%$, increasing by $22.48 \%$ compared with that at $20^{\circ} \mathrm{C}$, and it was increased by $4.94 \%$ at $50^{\circ} \mathrm{C}$. For the cost-effective and efficient removal of VSS, it was advantageous to maintain higher temperature. The maximum temperature obtained from self-heating was $64^{\circ} \mathrm{C}$ in the process.

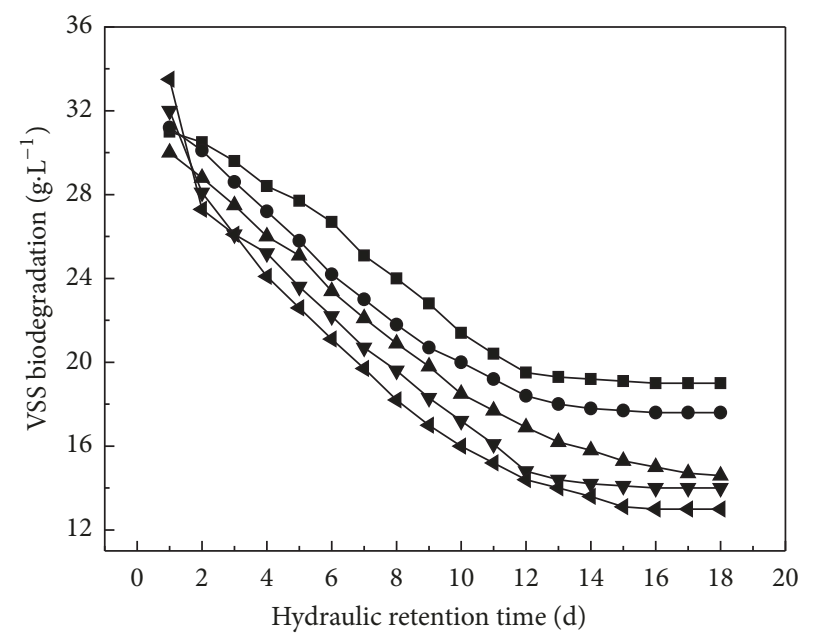

FIGURE 5: Effect of temperature on VSS degradation. Tempera-

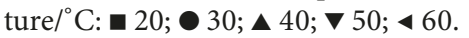

\section{Empirical Kinetic Model for VSS Biodegradation}

4.1. Arrhenius-Type Empirical Kinetic Model. The empirical kinetic model is an Arrhenius-type equation [19-21]. By dimensional analysis [22-24], the equation can be written as follows:

$$
\begin{gathered}
\frac{d(\mathrm{VSS})}{d t}=-k^{0} \exp \left(\frac{-\mathrm{Ea}}{R T}\right) \cdot \mathrm{VSS}^{m} \cdot O^{n} V^{q}, \\
\frac{d(\mathrm{VSS}) / d t}{d T}=-k^{0} \exp \left(\frac{-\mathrm{Ea}}{R T}\right) \cdot \mathrm{VSS}^{m} \cdot O^{n} V^{q} \cdot \frac{\mathrm{Ea}}{R T^{2}},
\end{gathered}
$$

where $k^{0}, \mathrm{Ea}, m, n$, and $q$ could be determined by experiments.

4.2. Regression Results and Model Validation. At different temperatures, the reaction rates were shown in Figure 5. The rate constant $k[\exp (-\mathrm{Ea} / R T)]$ in the model was obtained by the least square regression method. The regression was achieved from the second day to the twelfth day. The $k$ value was calculated from the regression equation. The results obtained are shown in Table 2.

By the logarithm of the Arrhenius formula, the relationship between $\ln k$ and $1 / T$ was obtained, which resulted in a straight line. From the slope, the apparent activation energy could be calculated, and from the intercept the factors can be obtained (as shown in Figure 6), which are $2.827 \mathrm{~kJ} \cdot \mathrm{mol}^{-1}$ and 


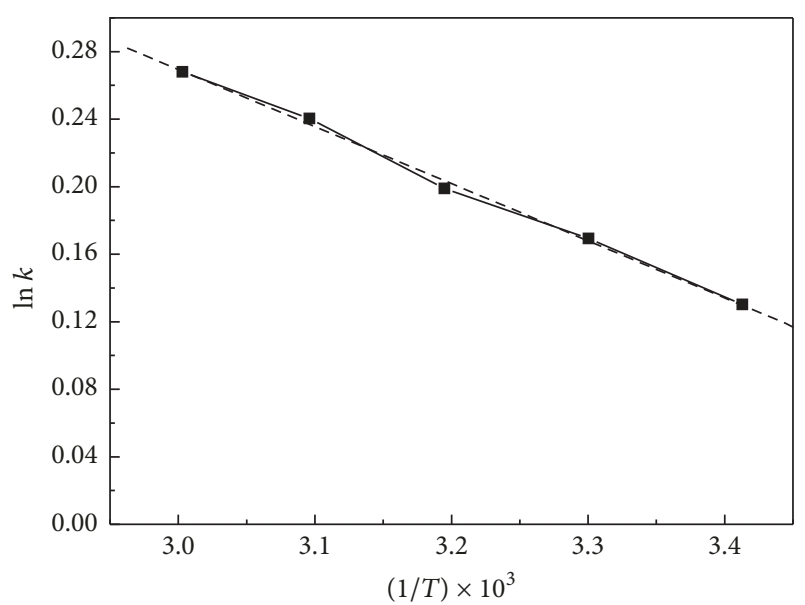

FIGURE 6: The relationship between $\ln k$ and $1 / T$. - - - regression coefficient of $0.9971 ;-\cdots-1 n k=1.2846-0.3384 / T$.

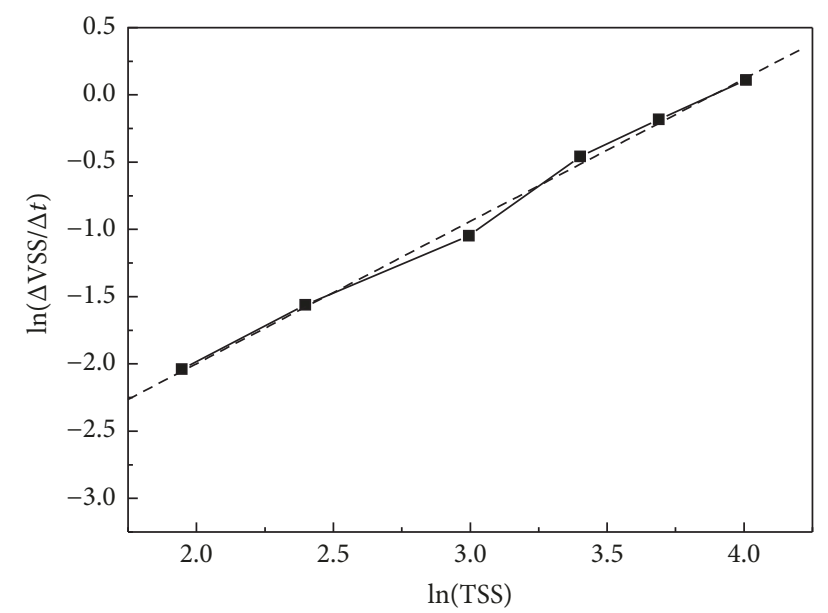

FIGURE 7: The relationship between VSS biodegradation rate and its concentrations. - - regression coefficient of 0.9955 for $m$; -----$\ln (\Delta \mathrm{VSS} / \Delta t)=1.05871 \ln (\mathrm{VSS})-4.1165$.

$3.59\left(\mathrm{~g} \cdot \mathrm{L}^{-1}\right)^{-1.0587} \cdot\left(\mathrm{ml} \cdot \mathrm{s}^{-1}\right)^{0.0976} \cdot\left(\mathrm{r} \cdot \mathrm{min}^{-1}\right)^{0.1618}$, respectively. The correlation coefficient for $k^{0}$ is 0.9971 . By substituting both sides of formula (1), the exponents $m, n$, and $q$ in the equation were obtained from the data in Figures 2, 3, and 4, respectively. The values of $m, n$, and $q$ are shown in Figures $7-9$, which are $1.0587,-0.0976$, and -0.1618 , respectively. The reaction order for VSS concentration is 1.0587 in this study, which is different from the first-order reaction kinetics obtained by Liu et al. $[25,26]$ for the aerobic sludge digestion or biological system [21].

The VSS concentration at time $t, \mathrm{VSS}_{t}$, was obtained according to (2) as follows:

$$
\begin{aligned}
\mathrm{VSS}_{t}= & \mathrm{VSS}_{0}-3.59 \\
& \times\left[\exp \left(-\frac{2826.76}{R T}\right)-\exp \left(-\frac{2826.76}{R T_{0}}\right)\right] \times t \\
& \times \mathrm{VSS}_{0}{ }^{1.0587} \times \mathrm{O}^{-0.0976} \times V^{-0.1618} .
\end{aligned}
$$

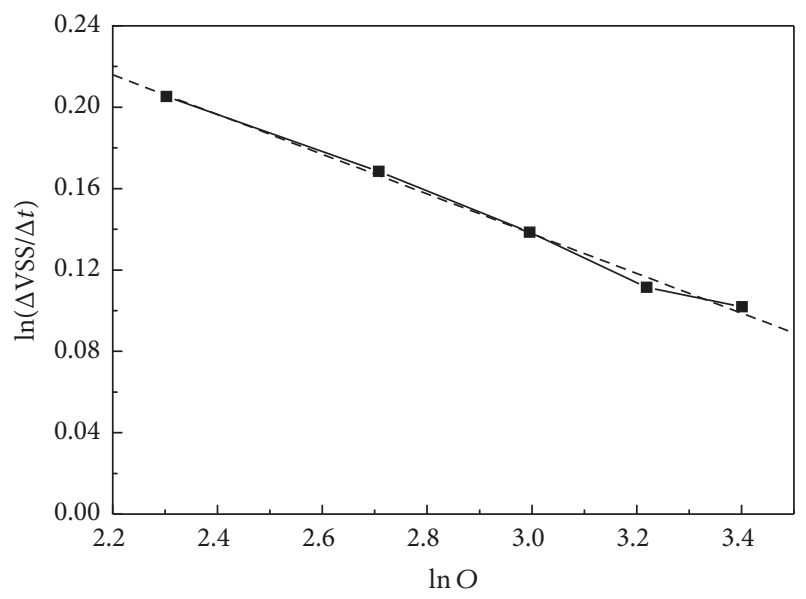

FIGURE 8: The relationship between VSS biodegradation rate and aeration rate. - - - regression coefficient of 0.9943 for $n$; -..--$\ln (\Delta \mathrm{VSS} / \Delta t)=0.4308-0.0976 \ln O$.

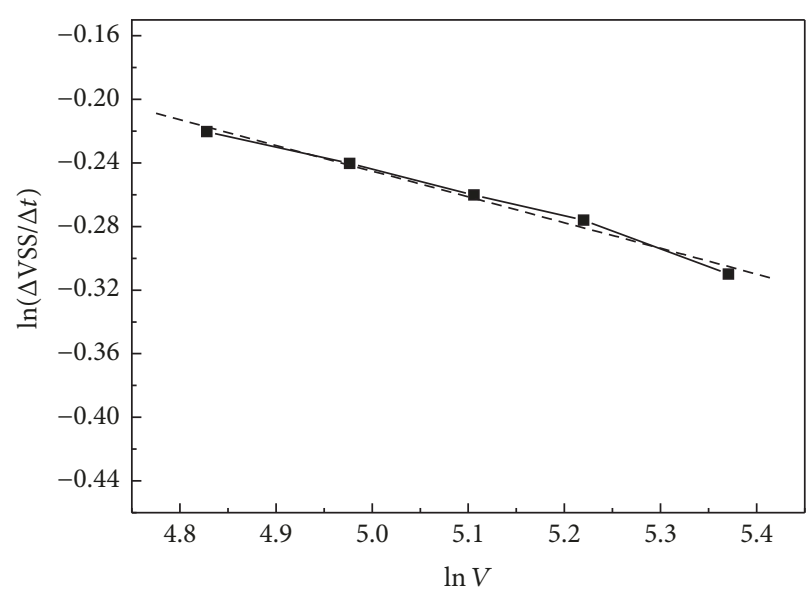

FIGURE 9: The relationship between VSS degradation rate and stirring rate. - - regression coefficient of 0.9872 for $q$; --.-$\ln (\Delta \mathrm{VSS} / \Delta t)=0.5637-0.1618 \ln V$.

The data calculated by (3) is compared with the average of the experimental data, which is shown in Table 3. Table 3 shows that the maximum deviation is $8.82 \%$, so the VSS removal efficiency can be predicted by (3).

\section{Microbial Community Structure Characteristics}

The sludge aerobic digestion system is affected by the digestion temperature and the source of sludge, and the population of thermophilic microorganisms is more complex. Studies have shown that there are clostridium species other than aerobic thermophiles in high temperature aerobic reactors. Based on OTU cluster analysis results, Table 4 shows the analysis of various types of bacteria and their share of the results.

As can be seen from Table 4, the sludge system showed a lower level of microbial population diversity; a total of seven species were detected. More than $89 \%$ of the thermophilic 
TABLE 3: Relative deviation between experimental and calculated VSS concentrations.

\begin{tabular}{|c|c|c|c|}
\hline Reaction time $(\mathrm{d})$ & Measured value (mg/L) & Calculated value $(\mathrm{mg} / \mathrm{L})$ & Relative deviation/\% \\
\hline \multicolumn{4}{|c|}{$40^{\circ} \mathrm{C}$} \\
\hline 3 & 27.5 & 26.88 & 2.25 \\
\hline 6 & 23.4 & 23.76 & -1.54 \\
\hline 9 & 19.8 & 20.64 & -4.24 \\
\hline \multicolumn{4}{|c|}{$50^{\circ} \mathrm{C}$} \\
\hline 3 & 26.1 & 27.38 & -4.90 \\
\hline 6 & 22.2 & 22.76 & -2.52 \\
\hline 9 & 18.3 & 18.14 & 0.87 \\
\hline \multicolumn{4}{|c|}{$60^{\circ} \mathrm{C}$} \\
\hline 3 & 26.1 & 27.5 & -5.36 \\
\hline 6 & 21.1 & 21.5 & -1.90 \\
\hline 9 & 17.0 & 15.5 & 8.82 \\
\hline
\end{tabular}

TABLE 4: ATAD reactor strain analysis.

\begin{tabular}{lcc}
\hline Serial number & Species name & Proportion/\% \\
\hline 1 & Bacillus stearothermophilus & $32 \%$ \\
2 & Bacillus thermocloacae & $22 \%$ \\
3 & Bacillus licheniformis & $15 \%$ \\
4 & Brevibacillus & $11 \%$ \\
5 & Sphaerobacter thermophilus & $9 \%$ \\
6 & Schineria larvae & $7 \%$ \\
7 & Clostridium & $4 \%$ \\
\hline
\end{tabular}

microorganisms in the device belong to the genus Bacillus, with a large number of Bacillus stearothermophilus being the most abundant species in Bacillus (32\% of isolates), followed by Bacillus stearothermophilus (22\% of isolates). In addition to the species of aerobic thermophilic bacteria in the system, there are other thermophilic microorganisms such as Schineria larvae and Clostridia. Ugwuanyi study found that only when the sludge digestion temperature is higher than $55^{\circ} \mathrm{C}$, the Bacillus stearothermophilus becomes the dominant population. When the digestion temperature was $50^{\circ} \mathrm{C}$, Bacillus licheniformis and Bacillus coagulans became the dominant species. The types of thermophilic bacteria are affected by sludge source and other factors. There may be great differences in the types of thermophilic bacteria in ATAD reactors of different wastewater treatment plants, but Bacillus plays a very important role in the reactor.

\section{Conclusions}

An empirical biodegradation kinetic model of Arrheniustype was obtained in the ATAD test for the treatment of piggery wastewater. The indices of VSS concentration, aeration rate, and agitation rate are $m, n$, and $q$, respectively. Each index is solved by logarithmic differential method. The values of $m, n$, and $q$ are $1.0587,-0.0976$, and -0.1618 , respectively. In the experimental temperature range, the apparent activation energy $\mathrm{Ea}$ is $2.827 \mathrm{~kJ} \cdot \mathrm{mol}^{-1}$, the preexponential factor $k^{0}$ is $3.59\left(\mathrm{~g} \cdot \mathrm{L}^{-1}\right)^{-1.0587} \cdot\left(\mathrm{ml} \cdot \mathrm{s}^{-1}\right)^{0.0976} \cdot\left(\mathrm{r} \cdot \mathrm{min}^{-1}\right)^{0.1618}$, and the correlation coefficient for $k^{0}$ is 0.9971 . The relative deviation between the data obtained from the empirical formula and the experimental data is less than $8.82 \%$. Sludge systems show a lower diversity of microbial populations. More than $89 \%$ of the thermophilic microorganisms in the device belong to the genus Bacillus. The model provides theoretical guidance for wastewater treatment and engineering design.

\section{Nomenclature}

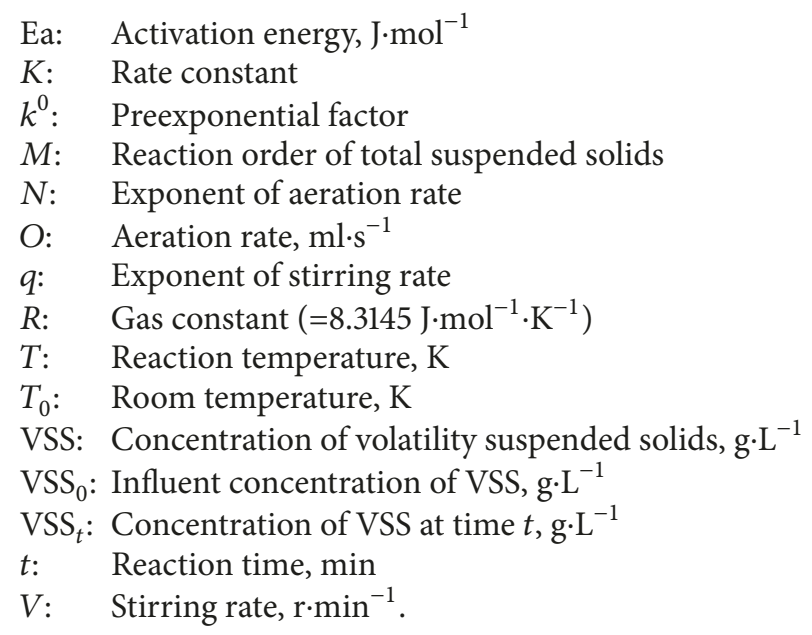

\section{Conflicts of Interest}

The authors declare that they do not have any commercial or associative interest that represents conflicts of interest in connection with the work submitted. 


\section{Acknowledgments}

This research was supported by the Foundation of Jilin Provincial Science and Technology Department of China (2012-09), no. 20170519015JH.

\section{References}

[1] Y. Z. Li, D. D. Sun, F. Y. Shi et al., "Effect of Mixing speed on VSS Reduction in Swine Wastewater Treated by Auto-thermal Thermophilic Aerobic Digestion," Journal of Anhui Agricultural Sciences, vol. 39, no. 15, pp. 9179-9181, 2011.

[2] Z. Han, J. Zhu, Y. Ding, W. Wu, Y. Chen, and R. Zhang, "Effect of feeding strategy on the performance of sequencing batch reactor with dual anoxic feedings for swine wastewater treatment," Water Environment Research, vol. 83, no. 7, pp. 643-649, 2011.

[3] J. Xu and G. Shen, "Effects of harvest regime and water depth on nutrient recovery from swine wastewater by growing Spirodela oligorrhiza," Water Environment Research, vol. 83, no. 11, pp. 2049-2056, 2011.

[4] X. Quan, C. Ye, Y. Xiong, J. Xiang, and F. Wang, "Simultaneous removal of ammonia, $\mathrm{P}$ and COD from anaerobically digested piggery wastewater using an integrated process of chemical precipitation and air stripping," Journal of Hazardous Materials, vol. 178, no. 1-3, pp. 326-332, 2010.

[5] L. Zhang, Y.-W. Lee, and D. Jahng, "Anaerobic co-digestion of food waste and piggery wastewater: Focusing on the role of trace elements," Bioresource Technology, vol.102, no. 8, pp. 5048-5059, 2011.

[6] Q. Zhang, "Method Research of Raising Methang Yield of Piggery Wastewater from Two-phase Anaerobic Treatment[D]," Journal of Northeast Electric Power University, 2016.

[7] F. Y. Shi, X. X. Zhan, and J. M. Liu, "Denitrification of Swine Wastewater by Alternating A / O Process," Journal of Northeast Electric Power University, vol. 31, no. 2, pp. 32-35, 2011.

[8] J. Zheng, Experimental Study on Preheating Assisted Enhanced Autothermal High Temperature Aerobic Digestible Sludge, Xi'an University of Architecture and Technology, 2011.

[9] N. M. Layden, "An evaluation of autothermal thermophilic aerobic digestion (ATAD)," Journal of Environmental Engineering and Science, vol. 6, no. 6, pp. 665-678, 2007.

[10] X. Li, H. Ma, Q. Wang, S. Matsumoto, T. Maeda, and H. I. Ogawa, "Isolation, identification of sludge-lysing strain and its utilization in thermophilic aerobic digestion for waste activated sludge," Bioresource Technology, vol. 100, no. 9, pp. 2475-2481, 2009.

[11] N. Jin, Z. Shou, H. Yuan, Z. Lou, and N. Zhu, "Selective simplification and reinforcement of microbial community in autothermal thermophilic aerobic digestion to enhancing stabilization process of sewage sludge by conditioning with ferric nitrate," Bioresource Technology, vol. 204, pp. 106-113, 2016.

[12] R. Y. Liu, X. F. Shi, Z. M. Ma, and Y. F. Li, "Dynamics and interrelating questions about sludge aerobic treatment," Liaoning Chemical Industry, vol. 31, no. 1, pp. 26-28, 2002.

[13] Y. F. Li, H. Ma, and X. H. Wang, "Dynamics and Relevant Questions about Sludge Aerobic Treatment," Journal of Shenyang Architectural \& Civil Engineering Institute, vol. 18, no. 2, pp. 132134, 2002.

[14] J. Gomez, G. M. De, E. Ayesa et al., "Mathematical modelling of autothermal thermophilic aerobic digesters," Water Research, vol. 41, no. 5, pp. 959-968, 2007.
[15] G. M. De, P. Grau, E. Huete et al., "New generic mathematical model for WWTP sludge digesters operating under aerobic and anaerobic conditions: Model building and experimental verification," Water Research, vol. 43, no. 18, pp. 4626-4642, 2009.

[16] M. J. Liu, H. S. Lv, Y. L. Chen et al., "Study on Advanced Treatment of Chemical Wastewater by Activated Carbon Biological Aerated Filter," Journal of Northeast Electric Power University, vol. 27, no. 4, pp. 91-94, 2007.

[17] J. H. Cheng, S. F. Zhang, H. Chen et al., "Effect of aeration rate on pilot technological process of autothermal thermophilic aerobic digestion (ATAD)," Technology of Water Treatment, vol. 32, no. 5, pp. 39-41, 2006.

[18] D. W. Riley and C. F. Forster, "The physico-chemical characteristics of thermophilic aerobic sludges," Journal of Chemical Technology \& Biotechnology, vol. 76, no. 8, pp. 862-866, 2010.

[19] G. R. Yang, H. L. Zhang, and Q. Liu, "Discussion on influencing factors of short-cut nitrification and denitrification in wastewater biological treatment," Journal of Northeast Electric Power University, vol. 32, no. 1, pp. 61-65, 2012.

[20] Ö. Altun and H. Akbaş, "The investigation of thermodynamic parameters of kinetic reaction between o-phenylenediamine and gold (III)," The Journal of Chemical Thermodynamics, vol. 39, no. 11, pp. 1413-1417, 2007.

[21] J. Liu, D. Sun, H. Liu, Y. Nie, and Z. Zhu, "Biodegradation kinetics for Pre-treatment of Klebsiella pneumoniae waste with autothermal thermophilic aerobic digestion," Chinese Journal of Chemical Engineering, vol. 18, no. 6, pp. 905-909, 2010.

[22] Y. H. Lai, M. X. Lu, C. Ma et al., "Study on the characteristics and dynamics of pyrolysis process agricultural residues," ActaEnergiae Solaris Sinica, vol. 23, no. 2, pp. 203-206, 2002.

[23] H. U. Yun, "Discussion about Dimension Analysis and its Application," Journal of Changjiang Engineering Vocational College, vol. 23, no. 3, pp. 52-54, 2006.

[24] H. Shukor, N. K. N. Al-Shorgani, P. Abdeshahian et al., "Production of butanol by Clostridium saccharoperbutylacetonicum N1-4 from palm kernel cake in acetone-butanol-ethanol fermentation using an empirical model," Bioresource Technology, vol. 170, no. 5, pp. 565-573, 2014.

[25] D. L. Su, J. L. Wang, K. W. Liu et al., "Kinetic performance of oil-field produced water treatment by biological aerated filter," Chinese Journal of Chemical Engineering, vol. 15, no. 4, pp. 591594, 2007.

[26] X. R. Sun and Z. J. Shan, "Removal of Di-n-butyl Phthalate Using Immobilized Microbial Cells," Chinese Journal of Chemical Engineering, vol. 15, no. 2, pp. 167-171, 2007. 

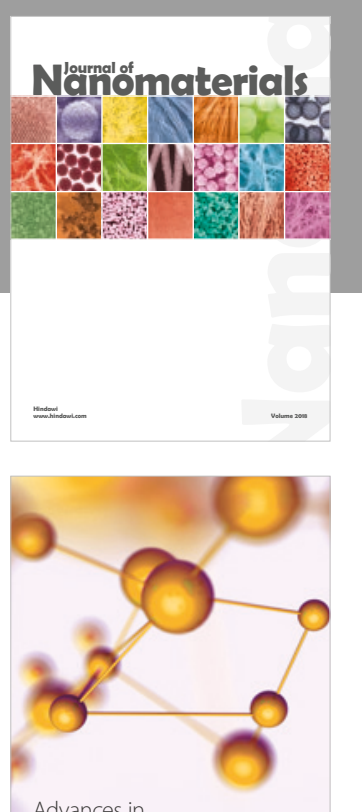

Physical Chemistry
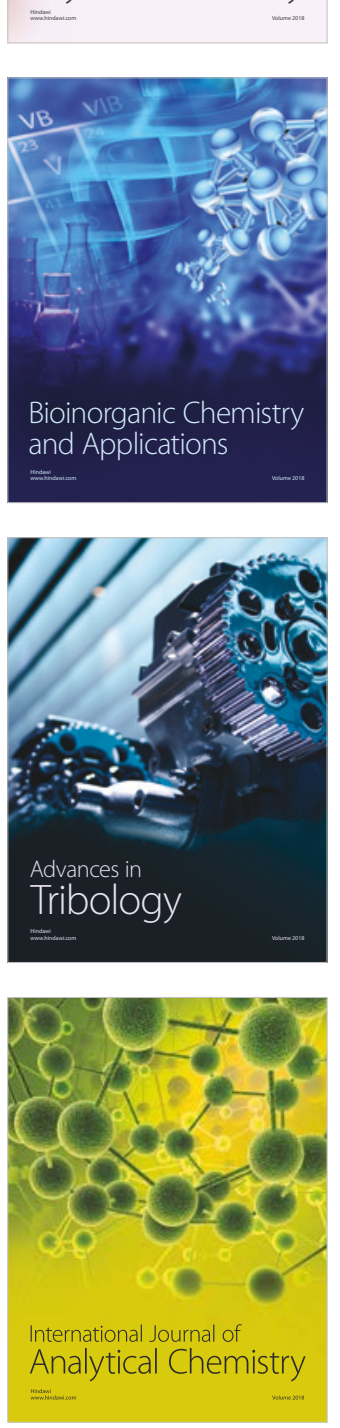

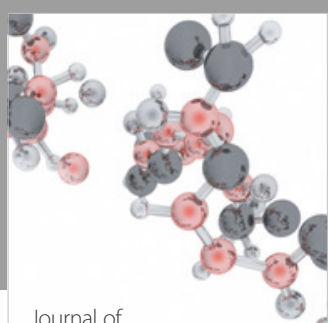

Analytical Methods

in Chemistry

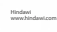

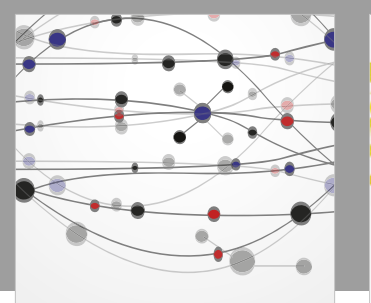

The Scientific World Journal

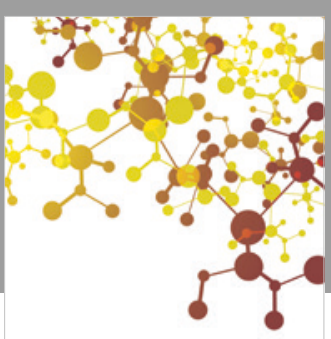

Journal of

Applied Chemistry
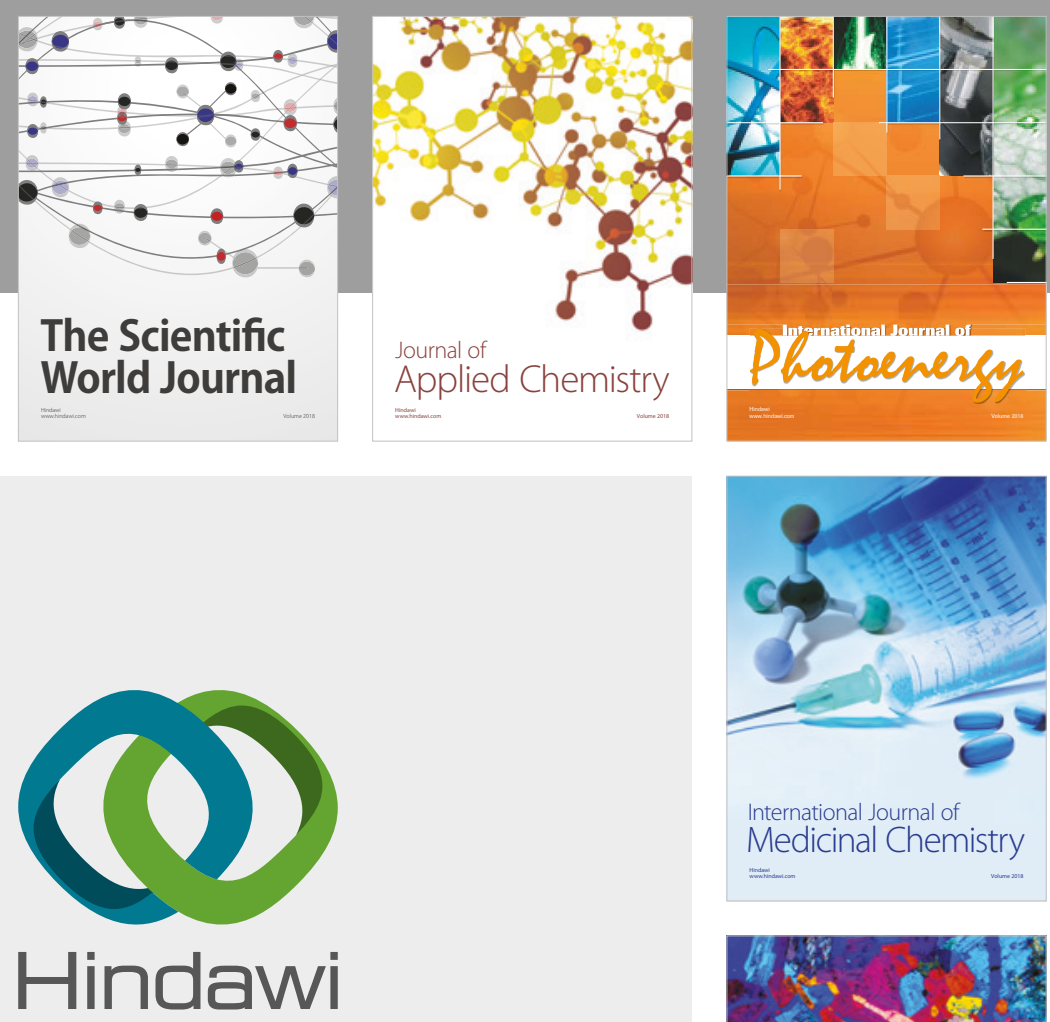

Submit your manuscripts at

www.hindawi.com
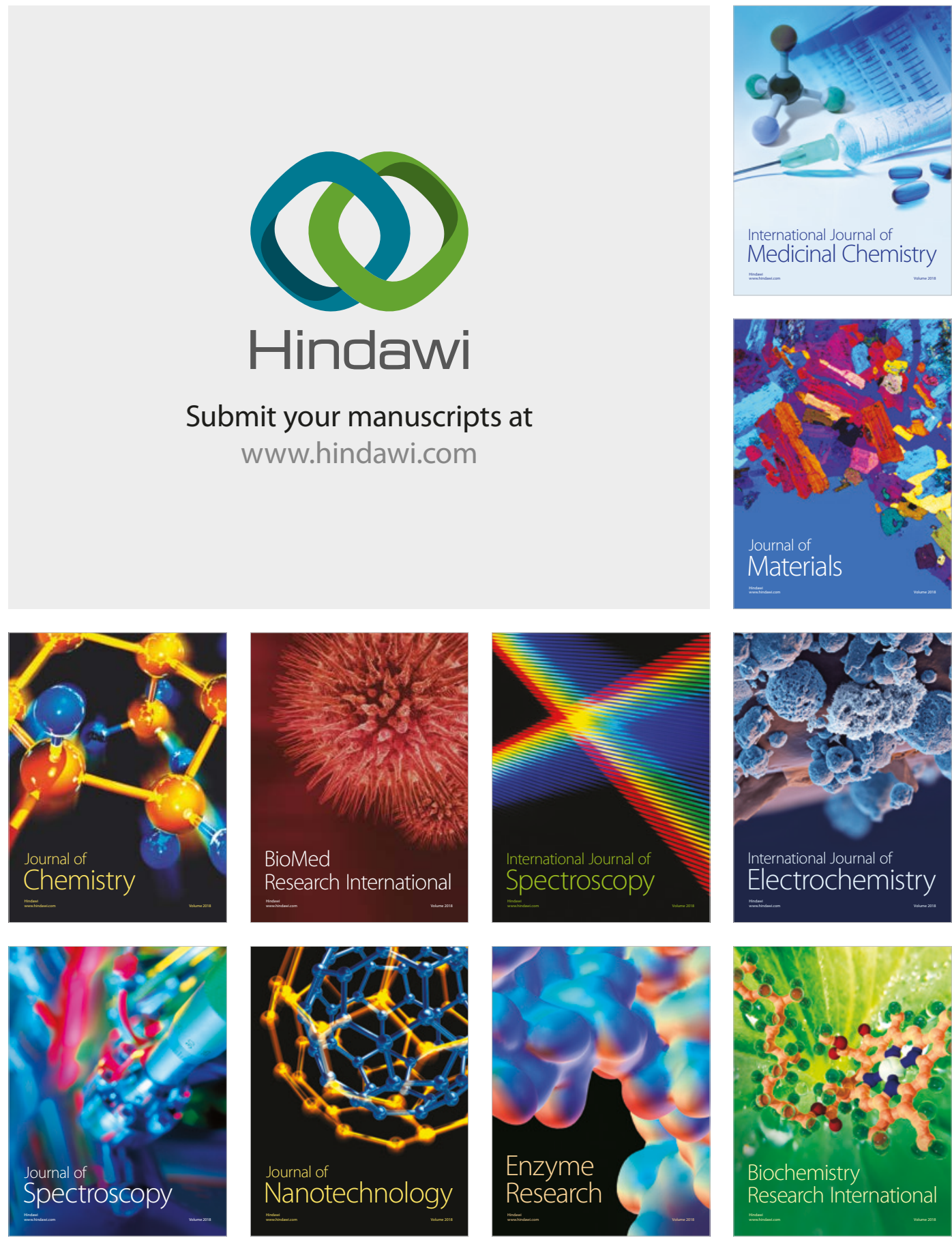
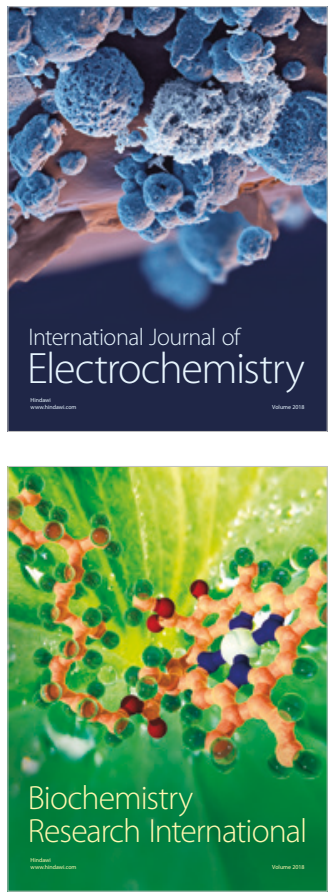